\title{
INVENTORY MANAGEMENT DESIGN FOR A RAPID DISASTER RELIEF, TOWARDS INTERNET OF THINGS (IOT) POTENTIAL
}

\author{
Muhammad Dachyar \\ Associate Professor ${ }^{1}$ \\ mdachyar@yahoo.com \\ Yadrifil \\ Senior Lecture \\ yadrifil@yahoo.com \\ Idrus Fahreza \\ Researcherl \\ idrusfahreza76@gmail.com \\ ${ }^{1}$ Department of Industrial Engineering \\ Universitas Indonesia \\ Jl. Margonda Raya, Pondok Cina, Kecamatan Beji, \\ Kota Depok, Jawa Barat 16424, Indonesia
}

\begin{abstract}
All victims in a disaster situation need rapid assistance, yet in some cases this goal not accompanied by an ideal recording system on their logistic inventory management. This study aims to achieve inventory management systems for disaster logistics and their delivery in a fast response time and to create a rapid disaster relief distribution process through the implementation of Internet of Things (IoT). In disaster management agencies, the Business Process Reengineering (BPR) approach and IoT implementation are used. The proposed model resulted in a 44.92 percent increase in the time efficiency of logistical relief distribution, which previously took 64.34 hours to 35.44 hours.
\end{abstract}

Keywords: Internet of things, disaster management, inventory management, business process reengineering.

DOI: $10.21303 / 2461-4262.2019 .001079$

\section{Introduction}

Disaster is a progression of occasions that compromise and disturb the lives and wellsprings of network vocations brought about by characteristic, non-common or human components, bringing about overwhelming setbacks, natural harm, and loss of property [1].

Logistics has an important role in disaster management, especially during pre-disaster, right after the disaster, and recovery. Effective, efficient and reliable logistics management is an important factor in disaster management. IoT has changed the way companies and consumers live their life. Until the end of 2018, the number of IoT devices connected to the internet has reached 7 billion and predicted to grow to reach 21.5 billion in 2025 [2]. This usage increment is very possible for IoT capabilities that can share, receive, and analyze data to meet business requirements faster. Shortly after a disaster occurs, poor coordination in inventory management for logistic relief can be a crucial problem [3]. This study aims to generate a new logistics inventory business process in a shortest response time, as an implementation of a rapid disaster relief distribution process by utilizing IoT potential. The distribute relief disaster emerges a logistic business process reengineering (BPR) concept for a prudent supply process of a plentiful (not limited) material such as food, tent, clothes, medicine, medical equipment, etc.

\section{Literature review}

\section{1. Emergency logistics}

Logistics is a process of planning, implementing, and controlling flow, as well as efficient, effective storage of goods, services, and related information, from the origin to receiving 
point for the purpose of adjusting to customer needs with the lowest total cost [4-6]. The above definition is not entirely relevant in emergency situations because of the different nature of the problem, operational objectives, and demand characteristics, such the people served and the urgency of the need for assistance in emergency logistics, explicitly different from commercial logistics [7].

Supply chains/logistics operations in disaster operating fields are designed to concurrently match the requirement and supply of products to be delivered such as meals, shelter, tents, and medications. The most significant objectives to be accomplished in offering disaster aid or urgent supply chains are cost-effectiveness, brief shipping times and elevated supply accessibility.

\section{2. Three-level logistic disaster agencies}

In a disaster situation, the disaster management agency is organized into three levels based on the scope of each area. As shown in Fig. 1, the highest level is held by the National Disaster Relief Agency where this level 1 organization responsible for monitoring all disasters that occur in Indonesia. Underneath there is a level 2 organization that is responsible for monitoring disasters that occur within the provincial region. At the last level, the organization that is closest to the disaster situation or district level agency who's the first to be responsible for providing relief assistance in its area. If the agency cannot handle the disaster, then the level 2 organization will act, and vice versa if the Provincial Agency can't handle the disaster occurring in its region, the National Disaster Relief Agency as the highest authority/level 1 organization will go down hand [8].

\section{3. Type of humanitarian relief}

Disaster emergency assistance to fulfill basic needs of victims is given by paying attention to minimum standards of basic needs and paying attention to priority to groups, along with some types of relief and minimum standards of giving [9]:

- Food Aid: Food assistance is provided in the form of food, or public kitchen. Food aid for vulnerable groups is given in special forms.

- Non-Food Assistance: Provided to disaster victims in a temporary shelter in post-disaster areas, such as cooking equipment, fuel, lighting, and various kinds of tools.

- Clothing Help: Such as personal equipment to protect themselves from the climate, maintain health and privacy.

\section{4. Internet of Things (IoT) in disaster management}

The term Internet of Things was first officially introduced in 2005 [10]. The term IoT refers to a network of interconnected objects that have a unique identity and communicate using standard protocols. Some previous studies discussed the application of IoT in disaster situations. Wang et al in his book propose a paperless system that can dynamically handle aspects of the disaster event command system [11], then it was developed in an ad hoc communication algorithm that can connect equipment to strengthen operations in postdisaster [12].

IoT has the ability to become one of the supportive techniques in a catastrophe scenario. Some regions of implementation include:

1) Minimizing and preventing disaster risk: monitoring various possibilities for communication disasters and geographic information systems.

2) Emergency response: real-time communication for assistance and timely responses.

3) Post-disaster: search for missing people with the help of internet.

Dynamic and terrain situations that sometimes lack of support emphasize the need for ability to make an efficient and appropriate decisions in limited time. IoT technology, which has the ability to deliver the latest information in real-time, can be the key to creating a dynamic workflow [13]. 


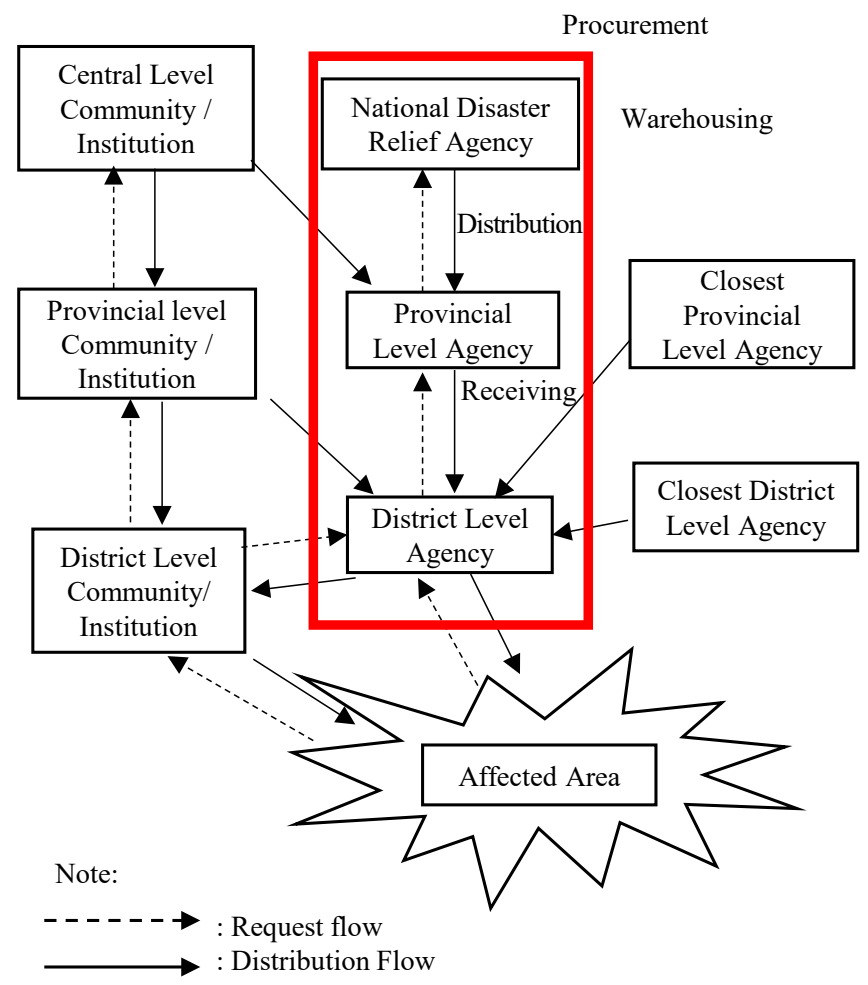

Fig. 1. Current distribution flow

\section{5. Data flow diagram (DFD)}

DFD is a graphical representation of network functional processes that are connected to each other by the flow of data. DFD often used as the main step to get a general overview of the system. According [14], DFD describes the movement of data from an external entity into the process and stored in the database. According to Shen [15] it is necessary to adopt more than one kind of modelling technique to establish a set of graphical models describing a system from different views. The modelling approach described in this paper is composed of three widely used modelling methods: IDEF0 to establish functional models, IDEF3 to capture process descriptions, and DFD to describe information/data flow among the activities. It is a staged approach in which different modelling method is used at different levels of granularity and details of information required. After a careful evaluation and comparison (including respective advantages and disadvantages, DFD is a tool that serves to reveal the relationships between several components in a system. On the other hand, Ibrahim [16] explains that DFD is effective for describing functional requirements for complex systems.

Data flow diagram consists of:

- user/terminator: unit outside the system (external entity) that provides input to the system or receives output from the system in the form of people, organizations, or other systems;

- process: activities that process input into an output;

- data flow: data flow on the system (between processes, between terminator \& process, and between processes \& data stores);

- data store: STORAGE of data in the database, usually in the form of a table.

\section{6. Business process reengineering (BPR)}

BPR is defined as a fundamental rethinking and radical redesign of business processes to produce dramatic improvements in critical performance measures such as cost, quality, service, and speed [17]. BPR is a business strategy management that focuses on designing the flow of information and material within an organization [18]. Some of the primary reasons businesses reengineer compa- 
ny processes are to enhance client service, decrease cycle times by decreasing non-added value-added operations, decrease manufacturing and/or service expenses and enhance performance [19].

\section{Method}

Through the method of business process engineering, data processing is carried out in several stages. Data collection is done through literature studies related to government documents and interviews with 4 experts with work experience of more than 10 years. The following are the phases of this research.

\section{1. Process mapping}

Information from the related literature is collected to design the current flow of disaster logistics relief distribution. The closest district agency to the affected area has an obligation to distribute aid first. If the buffer stocks of the district level disaster management agency cannot meet the needs of victims in the affected area, the district level agency can make a request to the Provincial level. Provincial level disaster management agency that receives requests from the district level can directly send their assistance without the need to develop a distribution plan first, but on the contrary, if with support from Provincial level agency the stock needed for assistance still can't be fulfilled, the Provincial level will make a request to the central level, in this context is National Disaster Relief Agency. National Disaster Relief Agency can directly send assistance to the provincial level agency which will then be forwarded directly to the district level.

Based on interviews and discussion data, it is estimated that the district level agency might not be able to fulfill the number of requests that were received by the affected victims equal to $35 \%$, $15 \%$ for provincial level, and $10 \%$ for the central level. When National Disaster Relief Agency with the existing stock has not been able to meet the needs of the victims, National Disaster Relief Agency will procure by asking some of their clients who think they can help meet those needs within the existing deadline, this activity is usually called direct appointment. And on several occasions, when National Disaster Relief Agency helped in the distribution of aid during the emergency response period, the disasters occurred could be categorized as national disasters, this could also trigger the opening access for international assistance (Fig. 2).

The As-is model broadly describes the situation in an emergency response situation where usually the first three days after a disaster occurs. Disaster Management Agency in initial conditions modeled Business Process Modeling Notation (BPMN) using iGrafx software. BPMNdivides the business process into Pool and Lane which consists of a process group. In this study, Pool represents a different party or organization while Lane represents a process group from the related Pool. There are 3 pools in this as-is model. Namely the District Level Agency pool, the Provincial level agency pool, and the National Disaster Relief Agency pool. This model has 9 lanes where each pool holds 3 lanes, namely inspection, distribution, and receiving. After the model is created, the model is validated first by the expert. Irrelevant processes are removed and processes that do not yet exist are added.

\section{2. Analysis of As-is model}

After the model is validated by the expert, the model is simulated. The results of this simulation are summarized in a time record as seen in Table 1. Avg Cycle shows the average overall processing time, Avg Work shows the amount of time active work done by the transaction and calculated from the time duration of the activity. Avg Wait is the amount of blocking time which in the model is defined as the waiting time process caused by the resource being used in another process, as well.

Inactive time is defined as the process waiting time caused by the resource being outside working hours.

The initial distribution process depicted in the as-is model shows the total duration for 1 disaster process, the average time obtained 64.34 hours. This duration consists of 29.5 working hours and 34.84 hours of waiting time. This time is quite representative of the situation. Conventional processes and time-consuming activities were then chosen to be the focus of improvements by applying IoT, so the time can be reduced to the expected average time. Problem identification is done through discussions with employees (Table 2). 


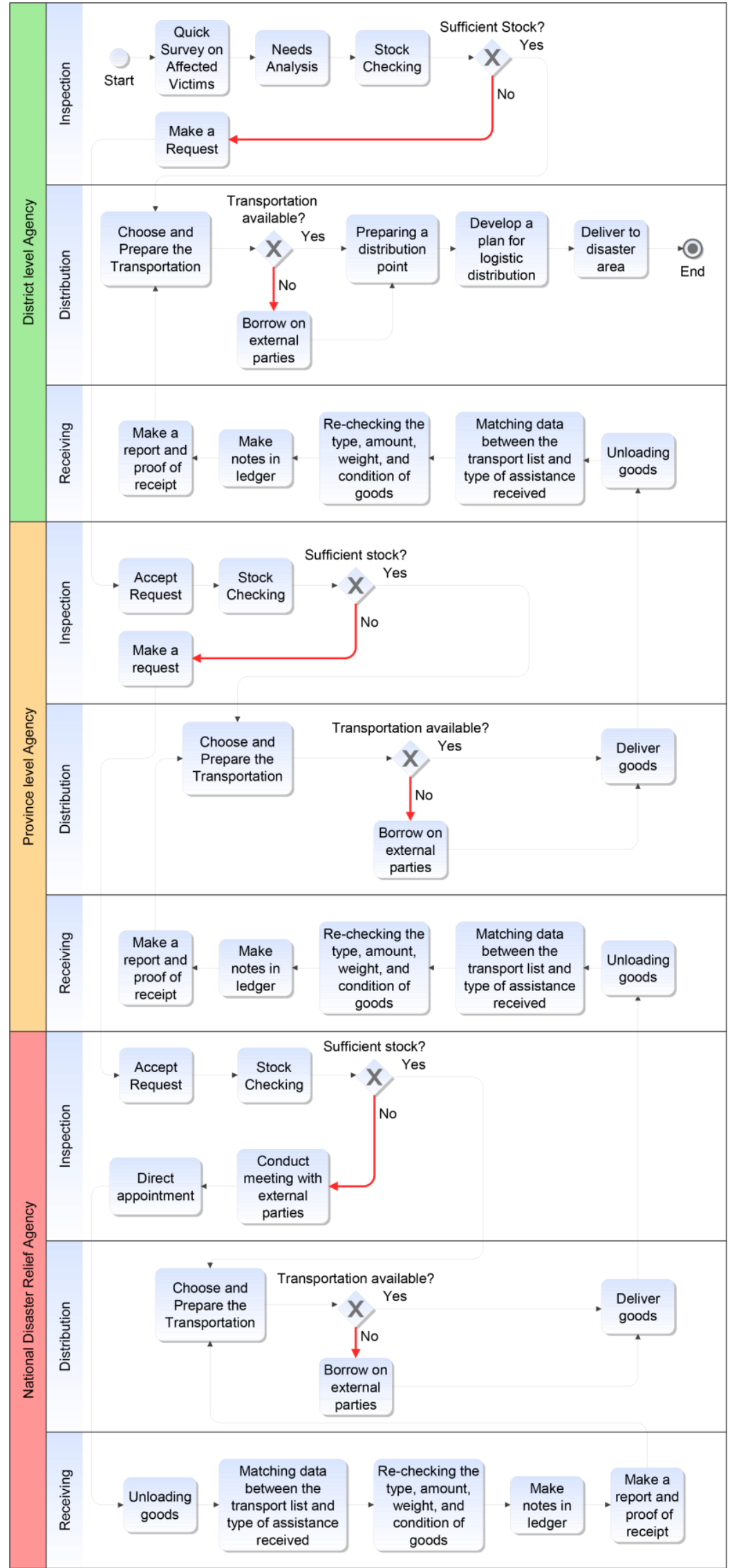

Fig. 2. Model of As-is logistics relief distribution process 
Table 1

Model as-is simulation result

\begin{tabular}{lccc}
\hline \multicolumn{1}{c}{ Process } & Avg Cycle (Hours) & Avg Work (Hours) & Avg Wait (Hours) \\
\hline District level Agency/Distribution & 26,51 & 12,84 & 13,67 \\
District level Agency/Inspection & 19,17 & 7,5 & 11,67 \\
District level Agency/Receiving & 9,33 & 6,33 & 3 \\
National Disaster Relief Agency/Distribution & 32,56 & 14,67 & 17,89 \\
National Disaster Relief Agency/Inspection & 13,48 & 6,44 & 7,04 \\
National Disaster Relief Agency/Receiving & 9,57 & 4,48 & 5,09 \\
Province level Agency/Distribution & 25,4 & 11,52 & 13,89 \\
Province level Agency/Inspection & 7,43 & 3,34 & 4,09 \\
Province level Agency/Receiving & 10,47 & 5,64 & 4,83
\end{tabular}

Table 2

Identification of problems in the initial condition of the aid distribution process

\begin{tabular}{|c|c|c|}
\hline Process & Problem & Solution with IoT \\
\hline $\begin{array}{l}\text { First check of } \\
\text { current stock }\end{array}$ & $\begin{array}{l}\text { Performed manually by checking each } \\
\text { item storage rack in warehouse }\end{array}$ & $\begin{array}{l}\text { Stock can be directly checked through a database and can be } \\
\text { viewed in real-time by a higher hierarchy }\end{array}$ \\
\hline Make a request & $\begin{array}{l}\text { Making a formal letter while requesting } \\
\text { help require amount of time }\end{array}$ & $\begin{array}{l}\text { Requests can be uploaded directly through the system and re- } \\
\text { ceived right away by the higher hierarchy }\end{array}$ \\
\hline $\begin{array}{l}\text { Make notes in } \\
\text { the ledger }\end{array}$ & $\begin{array}{l}\text { Recording is done manually for each item } \\
\text { received }\end{array}$ & $\begin{array}{l}\text { Recording is done automatically when scanning the } Q R \text { Code } \\
\text { where QR codes itself contain data from items that have been sent }\end{array}$ \\
\hline $\begin{array}{l}\text { Make a report and } \\
\text { proof of receipt }\end{array}$ & $\begin{array}{l}\text { Making report is sometimes not done } \\
\text { right after the item is received so that the } \\
\text { accountability process is hampered }\end{array}$ & $\begin{array}{l}\text { Through the database, all shipments that have been received will } \\
\text { be instantly updated in real-time }\end{array}$ \\
\hline
\end{tabular}

\section{3. Modeling To-be process}

The principle of IoTis connectivity between one object and another, for that there needs to be a sensor that attached to the object it is necessary to connect. From the problem, the authors proposed the application of QR Code as one of the solutions for implementing IoT. The following changes are made to relief distribution process with the application of IoT:

- Adding "Making QR Code" Process.

In this case, the item to be sent will be listed and brought by the courier until it finally rerecorded in receiving section. With IoT principle, the author intends to give an identity or sensor to the goods sent, so the item can be tracked when it has arrived at the receiving section and can be recorded automatically to the database after going through the approval process. QR Code is media the author uses to implement IoT, through the delivery point, information needed of the aid items are input to QR Code and transported directly with relief items sent.

- Adding "Scan QR Code” Process.

Through the QR Code that created at a distribution point, the transport list is no longer needed. At receiving section, the process of matching and inspection of goods, through a scan of QR Code, detailed information will appear regarding the items sent such as the item code, item name, and number of items, type of item, unit, and sender of the item. If the goods sent are in accordance with what is printed on the screen after the QR Code is scanned, then the recipient can immediately confirm through the system on their smartphone. The system will immediately update, so the proof record of handover can be received in real-time.

The application of the QR Code into the system which will later be applied to the to-be model is illustrated by the data flow diagram level 1 as seen in Fig. 3 where the QR Code will be the link between the distribution and acceptance processes. 


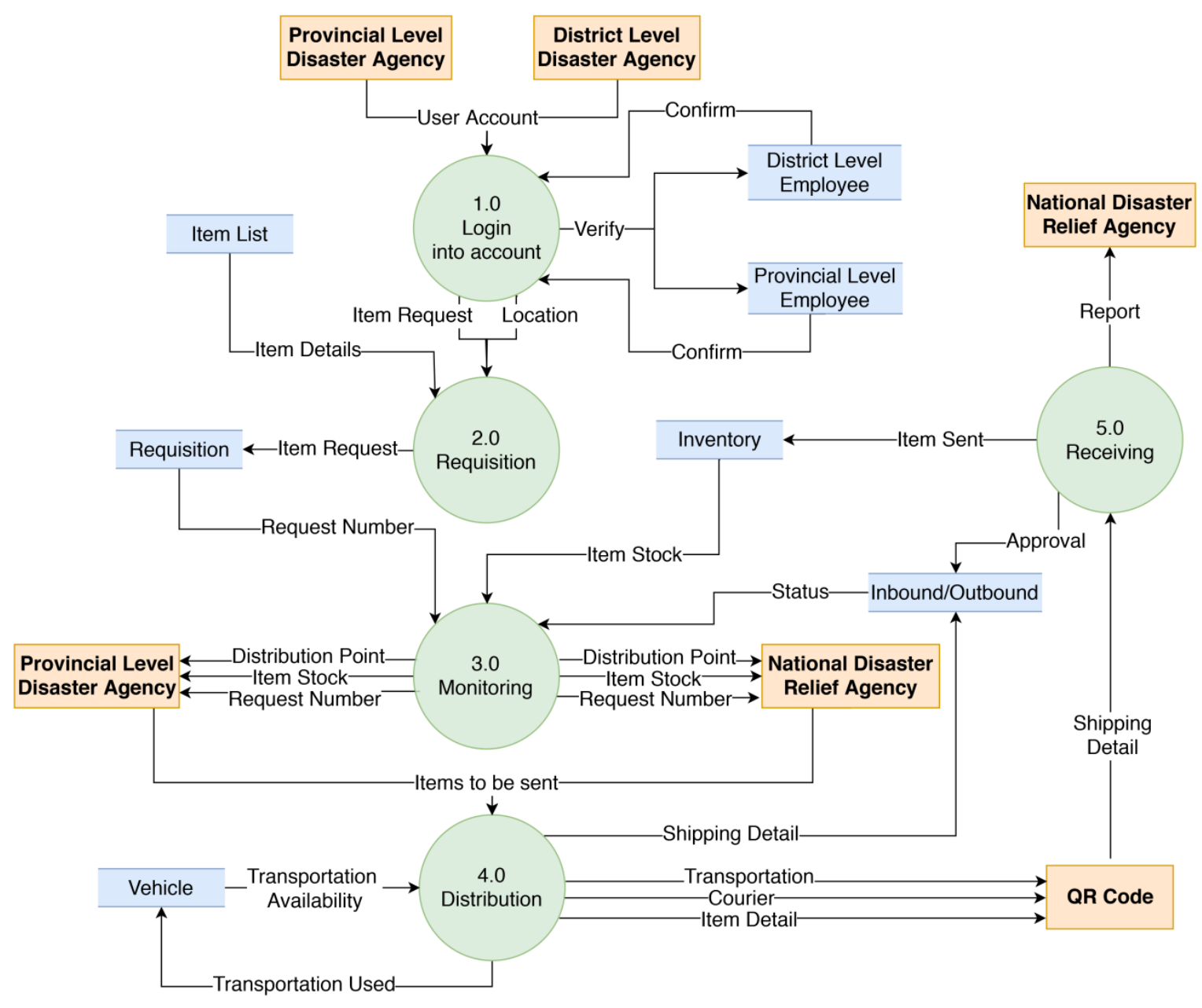

Fig. 3. Model of To-be data flow diagram

The application of the QR Code into the system which will later be applied to the to-be model is illustrated by the data flow diagram level 1 as seen in Fig. 3 where the QR Code will be the link between the distribution and acceptance processes.

Process starts when the Provincial level or District level agency sends a request, but for the identity recognition of the requester, at the same time knowing the location of the agency that sent the request, each of the requesters needs to login first. After their account is verified, the requester's identity will become clear.

Request made forwarded to the Provincial level for requests from district level, and to central level for requests from the Provincial level, after request received, the recipient of request can check the stock of goods owned by the requestor or the nearest agency stock at the same level as the requestor, if it has been ascertained that there is no stock in the region, distribution can be done, data regarding the sender, vehicle used and details of the goods sent are input into the QR Code so that later it can be directly scanned in the receiving process. After the approval process is carried out at the receiving point, relief will automatically enter the destination BPBD inventory system and the status of courier delivery in the inbound/outbound database will change.

Based on the distribution process model with IoT implementation, IoT provides enough changes compared to conventional as-is distribution processes. However, the problems identified at the as-is analysis phase are not fully resolved. Therefore, at this stage, improvements are made based on the best practices of BPR that researchers get through literature so that business processes can operate with a shorter time (Table 3). 
Table 3

Changes to the model through the application of best practice

\begin{tabular}{|c|c|c|c|}
\hline Best practice & Changes to the model & \multicolumn{2}{|c|}{ Lane } \\
\hline $\begin{array}{l}\text { Integral } \\
\text { technology }\end{array}$ & $\begin{array}{l}\text { Application of the QR Code as a medium for implement- } \\
\text { ing IoT so that the acceptance process can be faster and } \\
\text { accountable }\end{array}$ & \multicolumn{2}{|c|}{$\begin{array}{c}\text { National Disaster Relief Agency/Distribution, } \\
\text { Province level Agency/Receiving, District level } \\
\text { Agency/Receiving }\end{array}$} \\
\hline Integration & $\begin{array}{c}\text { Integration between the process of finding transportation } \\
\text { and the database of lenders so that the meeting time with } \\
\text { external and the choice of modes of transportation can be } \\
\text { reduced }\end{array}$ & \multicolumn{2}{|c|}{$\begin{array}{l}\text { National Disaster Relief Agency/Distribution, } \\
\text { District level Agency/Distribution, Province } \\
\text { level Agency/Distribution }\end{array}$} \\
\hline Parallelism & $\begin{array}{l}\text { Preparation of distribution points/storage warehouses is car- } \\
\text { ried out simultaneously with external meetings in lending } \\
\text { transportation so that the distribution process can be faster }\end{array}$ & \multicolumn{2}{|c|}{$\begin{array}{l}\text { Province level Agency/Distribution, District } \\
\text { level Agency/Inspection }\end{array}$} \\
\hline \multicolumn{4}{|c|}{$\begin{array}{l}\text { Integral Technology refers to the application of the existing QR Code technology, while inte- } \\
\text { gration here is specifically for the process of finding transportation and lending to external parties } \\
\text { wherein a disaster situation it currently takes around } 6 \text { hours to get the vehicle. The prior determi- } \\
\text { nation method is proposed with an intention that when the disaster occurs, the data from agencies } \\
\text { involved in prior agreement to lend their vehicles had been recorded, there is no need to ask or look } \\
\text { for which parties could lend the vehicle. Everything is prepared before the disaster occurred. This } \\
\text { is aided by a database in data collection. Then parallelism refers to process of preparing a ware- } \\
\text { house storage point which is previously carried out linearly if there is no transportation available } \\
\text { becomes a parallel where the two processes are borrowing from external parties along with the } \\
\text { preparation of warehouse points to be held together (Table 4). }\end{array}$} \\
\hline \multicolumn{4}{|c|}{ Table 4} \\
\hline \multicolumn{4}{|c|}{ Model to-be simulation result } \\
\hline & Avg Cycle (Hours) & Avg Work (Hours) & Avg Wait (Hours) \\
\hline District level A & ency/Distribution & 7,95 & 0,17 \\
\hline District level A & ency/Inspection & 5,58 & 4,83 \\
\hline District level A & ency/Receiving & 6,33 & 10 \\
\hline National Disast & r Relief Agency/Distribution & 8,37 & 3,99 \\
\hline National Disast & r Relief Agency/Inspection & 6,12 & 8,9 \\
\hline National Disast & r Relief Agency/Receiving & 2,3 & 5,06 \\
\hline Province level & gency/Distribution & 8,24 & 0,86 \\
\hline Province level & gency/Inspection & 1,1 & 0,44 \\
\hline Province level & gency/Receiving & 3,47 & 4,74 \\
\hline
\end{tabular}

All alternatives then realized in the to-be distribution process model (Fig. 4) shows the complete model of to-be distribution process. The green shape shows improvement made through the best practice gap. And the dark blue process is an improvement that is done through the application of IoT and Table 4 shows the results of model simulation.

\section{Result and discussion}

The initial distribution process depicted in the as-is model shows a fairly long duration, namely the total process average time for 1 cycle disaster simulation is equal to 64.34 hours. This duration consists of 29.5 working hours and 34.84 hours of waiting time. Waiting time contains in business processes is the amount of blocking time, which in the model is defined as waiting time process due to resources being used in other processes, as well as inactive time, which is defined as waiting time process caused by the resource being outside working hours. In the initial business process waiting time reached $54.15 \%$ of the total average duration. 
As the time Disaster Relief Agency implemented IoT, the total duration of the process become 48.14 hours with 25.94 hours working time and 22.19 hours waiting time. There was a decrease in waiting time of 8.59 hours. This reduction in waiting time is in line with previous research which said that IoT can accelerate the company's operational activities.

Improvement process was followed by the application of BPR best practice by researchers obtained through literature and based on the results of discussions and interviews. The total average duration of logistical distribution process during the disaster was 35.44 hours with 15.79 hours of waiting time. Working time has been reduced by 3.56 hours from business processes with the implementation of IoT and reduced by 9.86 hours from work time to business processes before repairs. If viewed through the total duration of the business process, the application of IoT can shorten the duration by $25.18 \%$ while after being corrected again with additional BPR best practices application the total duration is shortened by $44.92 \%$.

However, the new business process has a restriction in terms of the internet technology and IoT devices availability. According to our field study, one of a great earthquake happened in Palu Donggala 2018, it's made a total internet access blackout in a such emergency condition, even though National Disaster Relief Agency recorded a succeed communication internet was immediately recovered after an abundance support from telco operator to get internet access via satellite.

\section{Conclusion}

Disaster that continues to strike makes research in the field of mitigation even more developed. The right step in ensuring disaster management can reduce our vulnerability in dealing with it. A term Golden Time indicates that all actions and responses taken for the first 72 hours since a disaster strikes determine someone's life. Through the business process modeling, it is possible to estimate the impact for every decision in the real world.

This study has resulted in a disaster logistics inventory management process and its distribution in faster response time and makes the system where inventory records can follow the flow of aid out as fast as anything, where it becomes a weakness of conventional systems that still rely on manual recording for each supply. The proposed model improves the time efficiency of logistic relief distribution during disasters by $44.92 \%$ with the application of IoT and BPR best practices. Apart from all the improvements it has brought, this system relies heavily on internet connectivity in its implementation. For this reason, in order to establish this system, adequate infrastructure is needed in disaster emergency response situations.

\section{Acknowledgement}

Research granted by Universitas Indonesia - PITTA B 2019.

\section{References}

[1] National Disaster Relief Agency. Perka BNPB No 4 Tahun 2009 Tentang Pedoman Bantuan Logistik (2009).

[2] Lueth, K. L. (2018). State of the IoT 2018: Number of IoT devices now at 7B - Market accelerating. IOT Analytics. Available at: https://iot-analytics.com/state-of-the-iot-update-q1-q2-2018-number-of-iot-devices-now-7b/

[3] Mulyono, N. B., Ishida, Y. (2014). Clustering Inventory Locations to Improve the Performance of Disaster Relief Operations. Procedia Computer Science, 35, 1388-1397. doi: https://doi.org/10.1016/j.procs.2014.08.183

[4] Bowersox, D. J., Closs, D. J. (1996). Logistical management: the integrated supply chain process. McGraw-Hill Companies, 730 .

[5] Ballou, R. H. (1999). Business logistics management : planning, organizing, and controlling the supply chain. Upper Saddle River New Jersey: Prentice Hall, 681.

[6] Johnson, J. C., Wood, D. F., Wardlow, D., Murphy, P. R. (1999). Contemporary logistics. Prentice Hall, 608.

[7] Sheu, J.-B. (2007). Challenges of emergency logistics management. Transportation Research Part E: Logistics and Transportation Review, 43 (6), 655-659. doi: https://doi.org/10.1016/j.tre.2007.01.001

[8] National Disaster Relief Agency. Perka BNPB No 13 tahun 2008 Tentang Pedoman Manajemen Logistik dan Peralatan Penanggulangan Bencana (2008).

[9] National Disaster Relief Agency. Pedoman Tata Cara Pemberian Bantuan Pemenuhan Kebutuhan Dasar (2008).

[10] Ivanov, A. (2014). The Internet of Things. IEEE Design \& Test, 31 (3), 4-5. doi: https://doi.org/10.1109/mdat.2014.2335314 
[11] Wang, J., Rosca, D., Tepfenhart, W., Milewski, A. (2006). Incident Command System Workflow Modeling and Analysis: A Case Study. Proceedings of the 3rd International ISCRAM Conference, 127-136.

[12] Kamruzzaman, M., Sarkar, N. I., Gutierrez, J., Ray, S. K. (2017). A study of IoT-based post-disaster management. 2017 International Conference on Information Networking (ICOIN). doi: https://doi.org/10.1109/icoin.2017.7899468

[13] Sinha, A., Kumar, P., Rana, N. P., Islam, R., Dwivedi, Y. K. (2017). Impact of internet of things (IoT) in disaster management: a task-technology fit perspective. Annals of Operations Research. doi: https://doi.org/10.1007/s10479-017-2658-1

[14] Valacich, J. S., George, J. F. (2017). Modern systems analysis and design. Eighth edi. Pearson Education, Inc., 520.

[15] Shen, H., Wall, B., Zaremba, M., Chen, Y., Browne, J. (2004). Integration of business modelling methods for enterprise information system analysis and user requirements gathering. Computers in Industry, 54 (3), 307-323. doi: https://doi.org/10.1016/ j.compind.2003.07.009

[16] Ibrahim, R., Yen, S. Y. (2010). An Automatic Tool for Checking Consistency between Data Flow Diagrams (DFDs). World Academy of Science, Engineering and Technology, 615-619.

[17] Hammer, M., Champy, J. (2001). Reengineering the Company - A Manifesto for Business Revolution. Harper business, 19 (3), 271.

[18] Harvey, S., Millett, B. (1999). OD, TQM And BPR: A Comparative Approach. Australian Journal of Management \& Organisational Behaviour, 2 (3), 30-42.

[19] Dachyar, M., Christy, E. (2014). Designing Process Improvement of Finished Good On Time Release and Performance Indicator Tool in Milk Industry Using Business Process Reengineering Method. Journal of Physics: Conference Series, $495,012011$. doi: https://oi.org/10.1088/1742-6596/495/1/012011 